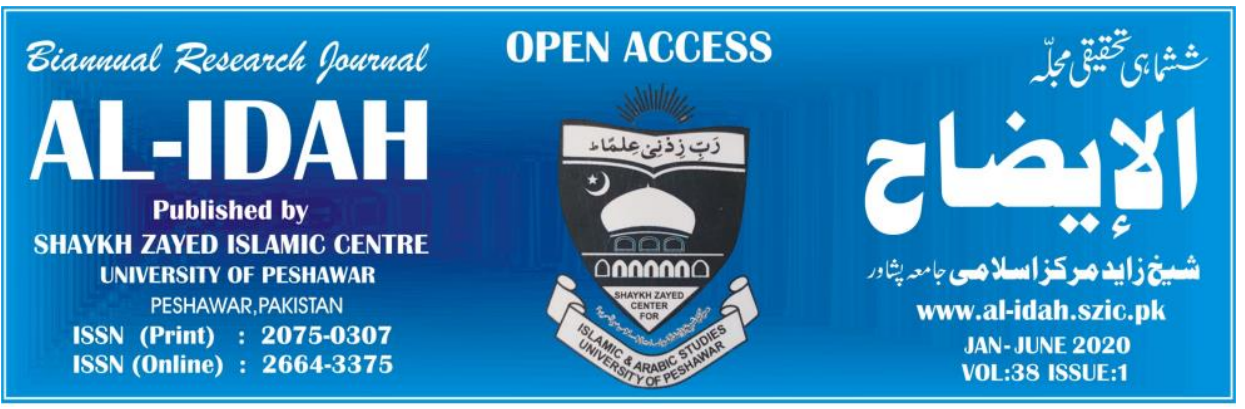

\title{
The Role of Traditional Elders in the Establishment of the Law and Order in FATA, PAKISTAN
}

\author{
Dr. Intikhab Alam \\ Lecturer, Department of Rural Sociology, The University of Agriculture \\ Peshawar
}

\section{Shahid Iqbal}

Centre for Disaster Preparedness \& Management, University of Peshawar Article DOI: https://doi.org/10.37556/al-idah.038.01.0348

\begin{abstract}
This study was carried out in Khyber Agency (FATA), with the main objective to determine the tribal thoughts towards the role of traditional elders in the establishment of law and order. The data was collected from randomly selected 380 sampled respondents, which includes people from commerce/trade community, students, Internally Displaced Persons (IDPs) and representatives from political administration was randomly drawn. To see the association between independent and dependent variables chi square statistics was used. The study reveals that the local people were not happy with the Malaks' role (traditional local leaders) for the reason of their personal interests which sustained their subjugation. It further indicates that the Malaks' role was weakened by the stronger influence of insurgents and even their tax collection act in view of the prevalent poor law and order situation. However, the Malaks' role was double-edged as they got benefits from the political administration on the one hand and looked for the insurgents' help in different issues on the other. Tribal elders remained silent over misdeed in the area. The local Malaks are enjoying like bourgeoisie class as political
\end{abstract}

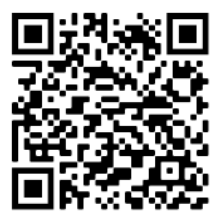

Scan for Download

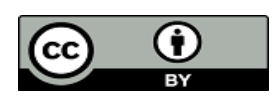


administration and masses are bound to go in accordance with their directions. They are not facing any kind of accountability for the financial benefits awarded by the political administration. The locals were found with oppressed feelings caused by the suppressive role of Malaks. Frontier crime Regulation (FCR) which is a tribal law has enshrined power to the local Malaks and political administration. The state law, which is not in vogue in the entire tribal belt, was observed as the only mechanism to bring normalcy by narrowing the spectrum of the Malaks' role and political administration. The local bourgeoisie (Malakān), operating around with all might enjoy and exercise on their part through a strong endorsement from the administration needs not to be overlooked. Their role must be defined under the provision of state law enshrined through constitutional cover. This would make them accountable and sense of accountability always brings honesty, dedication and loyalty. Moreover, oppressed feeling surfaced during the study from the local masses regarding the role of these Malak would also be brought under the umbrella of check and balance and thus democratic norms would prevail in aftermath.

Key words: Traditional Leaders, Insurgents, FCR and State Law

\section{Introduction:}

Elders are always making decision on the part of masses in all phenomena. Customary leadership always has a strong footing in the masses. They are representing their tribe on all occasions. Due to strong footing in the public and major role in the decision making, these elders are known as Arbāb, Khān and Malaks in their respective areas.

The troubled situation in FATA for the last so many decades in the tribal belt particularly in Khyber Agency is a serious threat to governance and maintenance of law and order. To accomplish sustainable peace efforts have focused on the capacity building of the local leaders in the area.

\section{A Brief History:}

Ashley (2009) has described that to protect British from tribal people's attacks they evolved a policy known as forward policy. This policy was based on "Non-aggression on tribal territory and non-interference in tribal affairs" was the reflection of defeat in the war (1838-42). The British government came to conclusion that defeating tribal belt and Afghanistan is not possible. Thus, they adopted the strategy of "masterly inactivity" or "close door policy" and they concentrated to develop relationships with tribal leaders in the area in NWFP and Afghanistan remained negligible. The security was planned by connecting roads with official forts along the administrative frontier to make possible intercommunication (Norris, 2000). 
At the same time peace-making measures were adopted. The British government signed treaties to achieve peace with the tribes. In return the government has won over Malaks through monetary benefits. The British officers were not permitted to enter the tribal areas whereas the tribal people were free to visit the settled area for trade/business (Majumdar, 1925). The FATA is composed of seven Agencies and PATA is composed of Malakand division and frontier regions. The PATA is governed by the respective provincial governments.

The provincial governments look after their respective tribal areas and the federal government took responsibility of FATA through Governor. The governor appointed political agent for seven agencies. Factors which influenced to control FATA by central government include hostile relationship with neighboring countries, as well as to tackle the issue of Pakhtūnistān and ethnicity-based nationalist politics in NWFP itself. Secondly, tribal areas are deprived parts in Pakistan. The British Government by design rather constrained and did not develop areas to govern the tribal areas. Regrettably since 1947 till date no government made any serious effort to carry out development activities in tribal areas. The change in the status of people of FATA remained a dream. No basic alteration occurred in the plan of the government regarding rulings and other administrative structure. The government was still dependent on local Malaks through respective political Agent in the tribal belt. The Political agent's office was used to establish contacts with tribal people through Malaks by not extending direct contacts or by not extending of basic rights to the people at grass-root level. At local levels allowances and subsidies were used to purchase loyalties.

The Native Administration (traditional leadership) today is the result of establishing rule of law in the area. The then governments of British and subsequent regime of Pakistan continue the policy of its predecessor in providing allowances and privileges to tribal chiefs to establish law and order. But the last forty years of instability in Afghanistan have deeply transformed the traditional leadership by warlords in FATA. Who are collecting taxes and running their own courts and administration in FATA by sidelining traditional leaders either by threat or have been killed by these insurgents.

Governments that came into power at different times did not concentrate on replacing the traditional administrative system in FATA. Ultimately, FATA remained a special target because the lasting power of customary Malaks controlled the writ of the state in the region. The destabilization of traditional leadership system has created radicalization in the region. Asmat (2012) pointed to the procedure for the appointment of Malaks much easier at present as compared to the difficult ones in the past. Previously, a candidate for Malak's position was supposed to undergo as an internee with the senior Malak before his appointment. The Political Agent was empowered to appoint a Malak.

Rana (2009) and Rakistis (2008) reported that Jirga is formed by the Political Agent of respective agency to supervise the trial and judgment process in a case. Under this system the right of appeal against the Jirga's decision was not allowed. The political Agent has the power to assigns anyone the title of Malak or withdraw it.White (2008) mentioned that the colonialist regime has restricted the 
jirga as a customary tribal practice that prevailed in a relatively democratic Pakhtūn culture to create a mechanism which is relevant to tribal people's customs.Bangash (1996) \& PLD (1954) describes that serious discrimination were carried out with citizens due to non- independent and help those who have some strong footing in the tribal culture. There is no mechanism of check and balance at the political administration level. The centralization of power in one office led to many issues and thus unlimited authority corrupts totally. The decision of Jirga "may run odd to the contemporary values prevailing dispensation of justice".

Bangash (1996) elaborated that Frontier Crimes Regulation (FCR) was a special collection of rules designed for controlling FATA by the British Empire in 1901. These rules were administered the turbulent areas in NWFP. FCR introduced joint responsibility of misdeed carried out by any members on the whole community. Traditional Jirga members, who are usually hereditary/nominated, make the decision of punishment. The accused were deprived of the right of appeal in opposition to the verdicts. The elders made in charge to maintain peace in the area.

Wilcox (1967) referred to indigenous mechanisms of disputes resolution of Pakhtūn society where elders of the tribe sit together to set aside the disputant matters through mutual consensus. The Britishers redefined the Malak system and entrusted the tribal Malaks with intermediate authority to help them in administering the tribal affairs smoothly. The Malaks were provided discretionary funds to use it for enhancing their local influence.

\section{Methodology:}

The major focus of this study was to look into the role of traditional leaders in establishing law and order in FATA, particularly Khyber Agency. A randomly selected 380 sample size that included political administration, intellectuals, internally displaced persons, business community and students were interviewed. 1. IDPs were the permanent inhabitants of the turbulent areas and they had clear understanding of the issue. The information received from them helped the researcher understand precisely the nature, intensity and direction of the study under investigation. Keeping a keen observation, they explicitly explained all the events damaging the writ of the State with all explicit and implicit interventions.

2. Business community is one of the key stakeholders of the study in terms of goods and services along with alignment to the other non- local markets. The business community information helped in giving worthy information in the study with relevant parameter as flow of money suffered with a number of gimmicks due to the investment of foreign currency into the local market for the purpose of paying to insurgents as salaries. This phenomenon not only ruined the business but also promoted the insurgents which later weakened the writ of the State in FATA. Business community was thought to provide valuable information about the improper governance and gave no opportunities of business in FATA.

3. Intellectuals: They included academicians, lawyers, journalists and political leaders. The first three categories are related to the issue of the writ of the state as they kept in touch themselves with it from their respective areas where as political 
leaders from FATA had an important role in reference to FCR, insurgency and other related affairs. Their contribution in regard to determining the direction of study and also in provision of information about the topic under study remained very much important.

4. Tribal students: The perception of tribal students studying at post graduate level teaching departments in University of Peshawar and University of Agriculture was to be sought on the issue. It is important to mention that the educated lot had knowledge about various factors weakening the writ of the State.

5. Political administration has been playing an important role in tribal affairs. All decisions relating to administration under FCR, insurgency and other threats to writ of the State come under its domain

\section{Tools of Data Collection:}

A wide-ranging interview schedule encircling approximately all features of the study was developed. The theoretical design of the Interview schedule was framed with seven parameters of independent variable: FCR, socio-economic deprivation, insurgency, foreign interference, traditional tribal elders, political vested interest and governance in vogue whereas dependent variable was the writ of the State. The interview schedule was pretested in order to remove any error or ambiguity or to add something more important for study before actual data collection process was started. A team of five paid investigators was hired and trained on the interview schedule. All the important sections of the interview schedule were thoroughly discussed with them and confusion was removed to obtain quality data. Various groups were selected as respondents were approached for interview on prior designed schedule as per their convenience. The whole task of data collection was carefully monitored by the researcher himself and this exercise took about 03 months in data accomplishment.

An interview schedule was developed which was based on mechanism evolved by Sekaran (2003). The Likert scale procedure was used to develop questions and data were collected from target stakeholders through it. Frequency and percentage were used in Univariate analysis whereas bivariate analysis was used to ascertain association between independent variable (the role of traditional leadership) and dependent Variable (law and order) by indexing and cross tabulating through the application of $x^{2}$-test statistics as outlined bTai (1978).

$\left(\chi^{2}\right)=\sum \sum\left(\mathrm{f}_{\mathrm{ij}}-\mathrm{F}_{\mathrm{ij}}\right)^{2}$

Where

$\mathrm{F}_{\mathrm{i}} \mathrm{F}_{\mathrm{j}} \quad \mathrm{F}_{\mathrm{ij}}$

$\left(\chi^{2}\right)=$ Chi-square for two categorical variables

$\mathrm{f}_{\mathrm{ij}} \quad=$ the observed frequencies in the cross-classified category at $i$ th row and jth column

$\mathrm{F}_{\mathrm{ij}} \quad=$ the expected frequency for the same category, assuming no association between variables under investigation

The formula simply apply one to take squared summation of the frequencies for each cell, divided by the expected frequency. The resulting frequency is distributed as chi-square with relevant degree of freedom. The degree of freedom is calculated as follows; 


$\begin{array}{lll}\text { Df } & = & (\mathrm{r}-1)(\mathrm{c}-1) \quad \text { where } \\ \text { Df } & = & \text { Degree of freedom } \\ \mathrm{r} & = & \text { the number of rows } \\ \mathrm{c} & = & \text { the number of columns }\end{array}$

\section{Problems Encountered:}

Apparent problems encountered during data collection included security concern .The data collection team accessed the sampled area on prior appointment of the political administration and political leaders (Malaks or Malakān). The team members, as trained already, put question very carefully to Malaks to avert any unwanted situation. Anyhow, the team successfully acquired the required data.

\begin{tabular}{|c|c|c|c|c|}
\hline Statements & yes & no & $\begin{array}{l}\text { Don't } \\
\text { know }\end{array}$ & Total \\
\hline $\begin{array}{l}\text { Residents of the area were not } \\
\text { satisfied with Malaks' role for their } \\
\text { personal interests }\end{array}$ & $285(75 \%)$ & $75(19.7 \%)$ & $20(5.3 \%)$ & 380 \\
\hline $\begin{array}{l}\text { Political administration bribed local } \\
\text { Malaks in shape of cash }\end{array}$ & $297(78.2 \%)$ & $51(13.4 \%)$ & $32(8.4 \%)$ & 380 \\
\hline $\begin{array}{l}\text { Tax Collection is carry out by tribal } \\
\text { people }\end{array}$ & $243(63.9 \%)$ & $117(30.8 \%)$ & $20(5.3 \%)$ & 380 \\
\hline $\begin{array}{l}\text { warlords were supported by local } \\
\text { Malaks }\end{array}$ & $265(69.7 \%)$ & $88(23.2 \%)$ & $27(7.1 \%)$ & 380 \\
\hline $\begin{array}{l}\text { Malaks are financially benefitted by } \\
\text { the political administration }\end{array}$ & $324(85.3 \%)$ & $41(10.8 \%)$ & $15(3.9 \%)$ & 380 \\
\hline $\begin{array}{l}\text { Local elders' role is inactive in } \\
\text { bringing peace to the area }\end{array}$ & $301(79.2 \%)$ & $54(14.21 \%)$ & $25(6.6 \%)$ & 380 \\
\hline $\begin{array}{l}\text { Tribal leadership remained } \\
\text { indifferent over misdeed of official } \\
\text { incharge of the agency }\end{array}$ & $297(78.2 \%)$ & $45(11.8 \%)$ & $38(10.0 \%)$ & 380 \\
\hline
\end{tabular}

\section{Result and Discussions:}

\section{Local tribal leadership role:}

Table-1 mentions that majority $(88.2 \%)$ believed Malaks as their established leaders in the area, reflecting their decisive role in introducing any change in the concerned area. The endorsement of Malaks' role in important decisions by the masses is consonant with the study findings of (Achakzai, 2012).Majority (78\%) showed their unhappiness over the role of Malaks for taking numerous kinds of benefits and perks etc. such annoyance sighs replacement of the existing tribal system. This result is in line with the conclusion of (Afridi, 2012).A big majority (85.5\%) respondent mentioned them as not 
taking interest in improvement of the lot of masses. These findings can be supported by (Asia Report, 2006). Moreover, they were also indifferent and silent over malpractices like smuggling, malfunction in bringing normalcy in areas and sustaining warlords as stated by $78.2 \%, 79.2 \%$ and $69.7 \%$ respectively. These findings are in line with those of SPARC (2004); Bangash (1996); PLD (1954); Shinwārī (2005).

\section{Table-1 local tribal leadership role:}

Source: Field Survey, 2012. Note :( values in parenthesis indicate percentage)

Traditional Leadership and Challenges in establishment of law and order:

Table-2 reflects relationship between Malaks' role and challenges to the law and order in Khyber Agency measured through bivariate. The data mentioned the Malaks' position important in situation to the rule of law which was observed as highly significant with $(\mathrm{P}=0.00)$. Moreover, the local people's perception towards these leaders was also reported highly significant $(\mathrm{P}=0.00)$ as unhappy in the background of their personal interests affecting the law and order. It is obvious from these affairs that Malaks although hold a central place of leadership but their function has remained in matter of concern due to corruption and vested interests gained from the political administration. There exists similarity between the study results and an article published in Daily News (2004) that the local elites are dependent on bribes taken from political administration as compensation for making local people subjugated to administrative orders. Local leaders were also benefitted from insurgents from inside and outside. This made Malaks' role unfavourable which was supported by a highly significant relationship $(\mathrm{P}=0.00)$. The financial support to Malaks by the political administration was due to their traditional role in the concerned agency that was admitted with a highly significant relationship of the variables. This variably embedded treatment between Malaks and tribal people aimed at the peace in the area which is in line with the contributions of Rasheed (2005) and Wylcox (1963).The study further reveals that taxes were collected by the local people which is a reflection of obscurity of administrative command/authority that a highly significant relationship $(\mathrm{P}=0.00)$ depicts in the table. A highly significant result $(\mathrm{P}=0.00)$ also endorsed that local Malaks and warlords were in association with one another in the context of getting financial benefits from the political administration. These results are similar with conclusions of Rasheed (2005) and Wylcox (1963) that show the monetary benefits of Malaks by the war lords. The study results indicate a highly significant association $(\mathrm{P}=0.00)$ oflaw and order with local elders'dormant role in bringing normalcy in area and their silence over the malpractices exercised by the political administration. 
Table-2 Traditional elders and Challenges to law and order in FATA

\begin{tabular}{|c|c|c|c|c|c|c|}
\hline Statements & & Agree & Disagree & Not sure & Total & Chi- squire \\
\hline \multirow{3}{*}{$\begin{array}{l}\text { At local level Malaks were } \\
\text { accepted as customary leaders }\end{array}$} & Agree & $131(39.1)$ & $189(56.4)$ & $15(4.5)$ & 335 & \multirow[t]{3}{*}{$21.422(.000)$} \\
\hline & Disagree & $12(27.3)$ & $28(63.6)$ & $4(9.1)$ & 44 & \\
\hline & Not sure & 0 & 0 & $1(0.26)$ & 1 & \\
\hline \multirow{3}{*}{$\begin{array}{l}\text { Due to personal benefits local were } \\
\text { unhappy with Malaks }\end{array}$} & Agree & $130(45.6)$ & $130(34.2)$ & $7(2.5)$ & 267 & \multirow[t]{3}{*}{$49.113(.000)$} \\
\hline & Disagree & $6(8.0)$ & $57(76.0)$ & $12(16.0)$ & 75 & \\
\hline & Not sure & $7(35.0)$ & $12(60)$ & $19(5.0)$ & 38 & \\
\hline \multirow{3}{*}{$\begin{array}{l}\text { Due to insurgents presence Malaks } \\
\text { were ineffective }\end{array}$} & Agree & $121(40.7)$ & $169(56.9)$ & $7(2.4)$ & 297 & \multirow[t]{3}{*}{$29.838(.000)$} \\
\hline & Disagree & $18(35.3)$ & $25(49.0)$ & $8(15.7)$ & 51 & \\
\hline & Not sure & $4(12.5)$ & $23(71.9)$ & $5(15.6)$ & 32 & \\
\hline \multirow[t]{3}{*}{ tribal people collected taxes } & Agree & $116(47.7)$ & $123(50.6)$ & $4(1.6)$ & 243 & \multirow[t]{3}{*}{$40.981(.000)$} \\
\hline & Disagree & $22(18.8)$ & $82(70.1)$ & $13(11.1)$ & 177 & \\
\hline & Not sure & $5(25.0)$ & $12(60.0)$ & $3(15.0)$ & 20 & \\
\hline \multirow{3}{*}{$\begin{array}{l}\text { Warlords were supported by local } \\
\text { leaders }\end{array}$} & Agree & $126(47.5)$ & $132(49.8)$ & $7(2.6)$ & 265 & \multirow[t]{3}{*}{$45.908(.000)$} \\
\hline & Disagree & $17(19.3)$ & $61(69.3)$ & $10(11.40$ & 88 & \\
\hline & Not sure & 0 & $24(88.90)$ & 3(11.1) & 27 & \\
\hline \multirow{3}{*}{$\begin{array}{l}\text { political administration } \\
\text { bribed local leaders }\end{array}$} & Agree & $128(39.8)$ & $184(56.8)$ & $12(3.7)$ & 324 & \multirow[t]{3}{*}{$14.725(.005)$} \\
\hline & Disagree & $11(26.8)$ & $23(56.1)$ & $7(17.1)$ & 41 & \\
\hline & Not sure & $4(24.7)$ & $10(66.7)$ & $1(6.7)$ & 15 & \\
\hline \multirow{3}{*}{$\begin{array}{l}\text { Tribal leaders were inactive in } \\
\text { establishing peace }\end{array}$} & Agree & $138(44.8)$ & $161(52.3)$ & $9(2.9)$ & 308 & \multirow[t]{3}{*}{$57.777(.000)$} \\
\hline & Disagree & $5(10.5)$ & $32(68.1)$ & $10(213)$ & 47 & \\
\hline & Not sure & 0.00 & $24(96.0)$ & $1(4.0)$ & 25 & \\
\hline \multirow{3}{*}{$\begin{array}{lll}\text { Malaks were indifferent over } \\
\text { misdeed of PA }\end{array}$} & Agree & $128(43.1)$ & $163(54.9)$ & $6(2.0)$ & 297 & \multirow[t]{3}{*}{$49.882(.000)$} \\
\hline & Disagree & $15(33.3)$ & 22(48.9) & $8(17.8)$ & 45 & \\
\hline & Not sure & 0,00 & $32(84.2)$ & $6(15.8)$ & 38 & \\
\hline
\end{tabular}

Source: Field Survey, 2012

\section{Conclusion and Recommendations}

It is concluded from the above results that the Malaks were recognized as traditional leaders, and political administration facilitated them through different means for the purpose to seek their help in administering the tribal affairs but the local people were not satisfied with local leaders due to individual benefits. Insurgents weakened the Malaks' role ineffective in view of the poor writ of the state and direct tax collection act by them. Malaks were blamed for their double standard of behaviour as they got benefits from both the political administration and insurgents. Malaks' role was also viewed as dominant in bringing about normalcy in the area as they remained silent over malpractices of political administration. It becomes clear that that the role of local elders was critical for the reasons mentioned in the preceding lines. They enjoyed like ruling class and considered the masses as proletariats where they were bound to comply with the commands of their local masters. The situation demands of redefining their role with provision of legal and constitutional support, so as their exploitation could no more prevail in the tribal areas and also make them accountable before the relevant institutions on the charge of malpractices they have exercised.

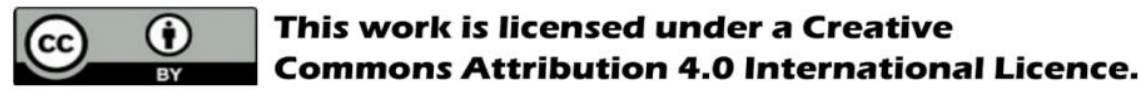




\section{NO T E:}

Asmatullah.(2012). Malaki System in FATA.Pp-3. (S. A. Chaudhry, Interviewer), Islamabad.

Alam, I., Muhammad, N., \& Shah, M. (2014).Frontier Crimes Regulation (FCR) and Writ of the State: A Study on Local People's Perception in Khyber Agency. Pakistan Journal of Criminology, 6(1), 295.

Alam, I., Muhammad, N., \& Shah, M. (2014).Frontier Crimes Regulation (FCR) and Writ of the State: A Study on Local People's Perception in Khyber Agency. Pakistan Journal of Criminology, 6(1), 295.

Bangash, A. M. (1996). Political and administrative development of tribal areas: A focus on Khyber and Kurram. Unpublished Ph. D. Dissertation, University of Peshawar. Pp-106.

Hanan, F. (2012). Causes and Effects of Drug Addiction with special reference to adoption of criminal behavior. MSc (Hons) Thesis, Department of Rural Sociology KPK Agricultural University, Peshawar. Pp-72.

Rakisits, C. (2010). Pakistan's Tribal Areas: A Critical No-Man's Land; paper delivered at Webster University Forum. Geneva: Accessed on 3rd March.

Rana, M. A. (2009). Taliban insurgency in Pakistan: A counterinsurgency perspective. Conflict and Peace Studies, 2(2), 12.

Rashid, A. (2000). Taliban. New Haven, CT: Yale University Press. Pp-130.

Sekaran, U. (2003). Research Methods for Business. USA. Hermitage Publishing Services.

Shinwari, I.(2005) Press under the FCR; paper read in seminar on "A bad law nobody can defend" which was organized by Human Rights Commission of Pakistan. 2005: pp 10; QasimKarim Printers, Lahore

Tai, S. W. (1978). Social science statistics, its elements and applications. Good year Pub. Co.

Tahir. A., et al. (2005).“Religious School Enrollment in Pakistan.” Washington, DC; Article Sep 23 2011 - 6:19am. The Committee Report.

Townshend. A. (2009).Anatomy of State Failure Case Studies in Zaïre, Afghanistan Studies in Conflict and Terrorism, 31: 7, .Pp. 775-80. Subcommittee on National Security and Foreign Affairs on March 4, 2009, 2-3.

White, T. J. (2009). Afghanistan and Pakistan: Understanding a Complex Threat Environment, Brief World Development Indicators Database. World Bank.

Wilcox, W. (1967). Book Review of "Aspects of the Frontier Crimes Regulation (FCR) in

Pakistan" by Willard Berry. The Journal of Asian Studies, 26 (3), 520-521

Davies, C. C. (1890). The Problem of the North-West Frontier 1890-1908, pp-21 cited in LalBaha, N.W.F.P. Administration, pp. 4.

Majumdar, R. C. \&et al. (1925).An Advanced History of India (London: Constable and Co. Limited), pp-761.

Norris, J. A. (1967).The First Afghan War, 1838-42, cited in Alan Warren, Waziristan, The Faqir of JPI, and the Indian Army (Karachi: Oxford University Press), 2000), pp$\mathrm{xx}$. 